\title{
Heterologous Expression of Recombinant Transglutaminase in Bacillus subtilis SCK6 with Optimized Signal Peptide and Codon, and Its Impact on Gelatin Properties
}

\author{
Shiting Wang ${ }^{1,2}$, Zhigang Yang ${ }^{3}$, Zhenjiang $\mathrm{Li}^{3 *}$, and Yongqiang Tian ${ }^{1,2 *}$ \\ 'Key Laboratory of Leather Chemistry and Engineering (Sichuan University), Ministry of Education, Chengdu \\ 610065, P.R. China \\ ${ }^{2}$ College of Biomass Science and Engineering, Sichuan University, Chengdu 610065, P.R. China \\ ${ }^{3}$ Chengdu Jinkai Bioengineering Co., Ltd., Chengdu 611130, P.R. China
}

\begin{abstract}
Microbial transglutaminases (MTGs) are widely used in the food industry. In this study, the MTG gene of Streptomyces sp. TYQ1024 was cloned and expressed in a food-grade bacterial strain, Bacillus subtilis SCK6. Extracellular activity of the MTG after codon and signal peptide (SP Ync M) optimization was 20 times that of the pre-optimized enzyme. After purification, the molecular weight of the MTG was $38 \mathrm{kDa}$ and the specific activity was $63.75 \mathrm{U} / \mathrm{mg}$. The optimal temperature and $\mathrm{pH}$ for the recombinant MTG activity were $50^{\circ} \mathrm{C}$ and 8.0, respectively. MTG activity increased 1.42fold in the presence of $\beta$-ME and 1.6-fold in the presence of DTT. Moreover, $18 \%$ sodium chloride still resulted in $83 \%$ enzyme activity, which showed good salt tolerance. Cross-linking gelatin with the MTG increased the strength of gelatin 1.67 times and increased the thermal denaturation temperature from 61.8 to $75.8^{\circ} \mathrm{C}$. The MTG also significantly increased the strength and thermal stability of gelatin. These characteristics demonstrated the huge commercial potential of MTG, such as for applications in salted protein foods.
\end{abstract}

Keywords: MTG, heterologous expression, signal peptide optimization, Bacillus subtilis SCK6, enzymatic properties

Received: February 26, 2020 Accepted: April 19, 2020

First published online: April 23, 2020

*Corresponding author Z.L.

Phone: +17790268754 E-mail: 396408786@qq.com Y.T.

Phone: +18980833138 Fax: +86-28-85405237 E-mail:yqtian@scu.edu.cn

pISSN 1017-7825 elSSN 1738-8872

Copyright(C) 2020 by The Korean Society for Microbiology and Biotechnology

\section{Introduction}

Transglutaminases (E.C. 2.3.2.13, TGases) are enzymes that catalyze cross-linking between the $\gamma$-carboxyamide group of a glutamine residue and the $\varepsilon$-amino group of a lysine residue [1]. TGases catalyze the formation of isopeptide bonds either within or between polypeptide chains and covalently incorporate polyamines into proteins with different primary amines, which eventually improve the solubility, thermal stability, water-holding capacity, and nutritional value of proteins [2]. TGases are widely distributed in various organisms, including humans, mammals, plants, and microorganisms [3]. In animals, TGases play an important role in various physiological processes [4] and neurodegenerative diseases [5], for which calcium $\left(\mathrm{Ca}^{2+}\right)$ is required to expose cysteine residues in the active site domain [6]. Microbial TGases (MTGs) have unique advantages in industrial applications due to their $\mathrm{Ca}^{2+}$ independence, higher reaction rate, lower molecular weight, wide range of $\mathrm{pH}$ stability and broad substrate specificity [2]. MTG was first discovered in S. mobaraensis in 1989 and then gradually isolated from Streptoverticillium spp., Streptomyces spp., Bacillus spp., and some pathogenic strains, including Candida albicans $[2,5,7,8]$. It has been widely used in the food industry to improve the functional properties and nutritional value of proteins. In recent years, MTG has shown application prospects in the cosmetic, textile, leather, pharmaceutical, and biomaterial sectors $[2,9]$.

Streptomyces MTG was first synthesized as an inactive zymogen and then processed to produce an active enzyme by removing N-terminal propeptide [10]. As production of active Streptomyces MTG causes cell death by cross-linking host proteins [11], MTG is usually expressed in a heterologous host in the form of pro-MTG. The proenzyme obtained by heterologous expression is converted to active MTG by coexpressing the protease [12] or by in vitro addition of activation protease [13]. To improve the yield of Streptomyces MTG, various hosts such as Escherichia coli [14], Streptomyces lividans [15], methylotrophic yeasts [16], Corynebacterium glutamicum [17], and Yarrowia lipolytica [3] have been investigated for heterologous expression.

Due to its nonpathogenic safety and high secretion properties, the expression host Bacillus subtilis is recommended by the US Food and Drug Administration and has been widely used as a host for heterologous protein expression. Compared with E. coli-based expression systems, the high secretion capacity of Bacillus 
subtilis provides better folding conditions and prevents the formation of inclusion bodies (IBs), which are biologically inactive [18]. Signal peptide plays a vital role in the translocation of secretory proteins across the plasma membrane. B. subtilis have four types of secretion pathways, most of which are the general secretion (Sec) pathway and the twin arginine translocation (Tat) pathway. The Sec-dependent secretory pathway is involved in secreting preprotein complexes with chaperone proteins, which bind to secreted transposases and facilitate transport across the plasma membrane. After removal of the signal peptide, the protein is released from the translocase and it refolds and passes through the cell wall [18-20]. Tian et al. [21] reported that the extracellular recombinant keratinase activity with the optimized signal peptide $\left(\mathrm{SP}_{\mathrm{LipA}}\right)$ was two times more than that of the wild type in Bacillus subtilis SCK6. Similarly, the recombinant amylase-producing strain with the best performing signal peptide $\left(\mathrm{SP}_{\mathrm{pel}}\right)$ yielded $68.4 \%$ more amylase than the natural strain [22]. Besides, codon optimization was also a commonly used method to increase the extracellular expression of proteins. Song Liu et al. [23] reported that the optimization of MTG gene based on the codon bias of Streptomyces increased MTG production by $73.6 \%$ in recombinant $S$. lividans.

To date, little research has been conducted on the heterologous expression of MTG in Bacillus. Since MTG is mainly applied in the food industry, Bacillus subtilis can secrete proteins outside the cell and is a better host for extracellular production of active-form TG. In this study, MTG with optimized codon and signal peptide was cloned and expressed in B. subtilis SCK6. Recombinant MTG was purified by ammonium sulfate precipitation and SP separation column. The active MTG was used to cross-link gelatin to provide evidence for the potential application of gelatin.

\section{Materials and Methods}

\section{Bacterial Strains and Vectors}

MTGase-producing bacterium Streptomyces sp. TYQ1024 (GeneBank Accession No. MN606211) was maintained in our laboratory. Escherichia coli DH5 $\alpha$ (Vazyme, China) was used for vector construction. Bacillus subtilis SCK6 (BGSC 1A976) (Erm R, his, nprR2, nprE18, $\Delta$ aprA3, $\Delta$ eglS102, $\Delta$ bglT/bglSRV, lacA::PxylA-comK) was used as the expression host [24]. pMA0911 with Tat (Ywb N, Lip A, Amy X, Wap A) and Sec (Ync M, Npr E, Vpr, Yvg O) signal peptides was used as the expression vector.

\section{Cloning and Expression of MTG}

Genomic DNA was extracted as described previously [25]. The DNA sequence encoding MTG was amplified using forward primer (5'-CGCGGATCCTCGCCACCGGCAGTGGCAGTGGCAGCG-3') with a BamHI recognition sequence and reverse primer (5'-CTAGCTAGCTCACGGCCAGCCCTGTGTCA-3') with a NheI recognition sequence (GeneBank Accession No. MN700931). The ligation recombinant plasmid was transformed into $E$. coli DH5a, and the transformants were inoculated on Luria-Bertani (LB) agar plate containing ampicillin $(100 \mu \mathrm{g} / \mathrm{ml})$ and incubated for $12 \mathrm{~h}$ at $37^{\circ} \mathrm{C}$. The recombinant plasmid was amplified and verified by DNA sequencing (Sangon Biotech, Shanghai, China). One microliter of the recombinant plasmid was mixed with $100 \mu \mathrm{l}$ of B. subtilis SCK6 competent cells and was allowed to grow in a shaking incubator $(200 \mathrm{rpm})$ at $37^{\circ} \mathrm{C}$ for $90 \mathrm{~min}$ [26]. The competent cells were cultured overnight on LB agar plates with kanamycin $(50 \mu \mathrm{g} / \mathrm{ml})$ at $37^{\circ} \mathrm{C}$. A positive clone was identified by PCR and shaken in a flask of LB liquid medium containing $50 \mathrm{mg} / \mathrm{l} \mathrm{kanamycin} \mathrm{for} 12 \mathrm{~h}$. Then, $3 \%$ seed culture was inoculated into a fresh liquid fermentation medium with $50 \mathrm{mg} / \mathrm{l}$ kanamycin and allowed to grow in a shaking incubator $(200 \mathrm{rpm})$ at $37^{\circ} \mathrm{C}$ for $60 \mathrm{~h}$.

\section{Codon and Signal Peptide Optimization of MTG Gene for Expression in Bacillus subtilis SCK6}

The coding region of MTG was chemically synthesized (Sangon Biotech, China) according to its preferred codon usage in the Bacillus strains. The codon-optimized MTG open reading frame (ORF) was cloned into the BamHI-NheI sites of pMA lipA, and the sequence of this synthesized fragment in pMA lipA-TGSO was confirmed by sequencing.

The recombinant plasmid was constructed and expressed as follows: pMA lipA-TG, pMA lipA-TGSO, pMA Ync M-TGSO, pMA Amy-TGSO, pMA wapA-TGSO, pMA Ywb N-TGSO, pMA Npr E-TGSO, pMA Vpr ETGSO, pMA Yvg O-TGSO. The amplified MTG gene was ligated to pMA 0911 with different signal peptides to construct the expression vector.

\section{MTG Activity Assay}

Transglutaminase activity was measured via hydroxamate assay [27] with few modifications. The culture supernatant $(100 \mu \mathrm{l})$ was mixed with the substrate solution $(1 \mathrm{ml})$ with $30 \mathrm{mM} \mathrm{CBZGln}-\mathrm{Gly}, 0.2 \mathrm{M}$ Tris-HCl buffer (pH 6.0), $10 \mathrm{mM}$ glutathione and $100 \mathrm{mM}$ hydroxylamine, and allowed to react at $37^{\circ} \mathrm{C}$ for $10 \mathrm{~min}$. Then, the reaction was stopped by adding ferric chloride trichloroacetic acid reagent. The TG activity was determined at the absorbance of $525 \mathrm{~nm}$. The calibration curve was prepared with L-glutamic acid $\gamma$-monohydroxamate. One unit of enzyme activity was defined as the amount of enzyme required to produce $1 \mu \mathrm{mol}$ of hydroxamic acid per minute at $37^{\circ} \mathrm{C}$.

\section{Purification of Recombinant MTG}

The fermentation broth was centrifuged at 7,000 $\times \mathrm{g}$ for $10 \mathrm{~min}$ to remove the precipitate. Ammonium sulfate was added to a final saturation of $50 \%\left(25^{\circ} \mathrm{C}\right)$ of the pellet supernatant and centrifuged at 7,000 $\times \mathrm{g}$ for $20 \mathrm{~min}$ to remove the pellet. Ammonium sulfate was again added to a final saturation of $80 \%\left(25^{\circ} \mathrm{C}\right)$, and the supernatant was centrifuged at 7,000 $\times \mathrm{g}$ for $20 \mathrm{~min}$ to obtain a precipitate. The precipitate was dissolved in $20 \mathrm{mM}$ sodium 
phosphate buffer (PB; pH 5.8) and centrifuged to remove the pellet. The supernatant was chromatographed on a SP Sepharose Fast Flow column previously equilibrated with buffer A (PB; pH 5.8). Adsorbed MTG was eluted with a linear gradient of sodium chloride $(\mathrm{NaCl} ; 0-1 \mathrm{M})$. The active fractions were combined and stored at $-20^{\circ} \mathrm{C}$. SDS-PAGE was performed using $12.5 \%$ separating polyacrylamide gel for establishing the purity and the molecular mass of the MTG.

\section{Biochemical Characterization of MTG}

To determine the optimal $\mathrm{pH}$ of MTG, substrate solutions of different $\mathrm{pH}$ were prepared. We used $100 \mathrm{mM}$ citrate buffer in the $\mathrm{pH}$ range $3-5,100 \mathrm{mM}$ phosphate buffer in the $\mathrm{pH}$ range 6.0-8.0, Tris- $\mathrm{HCl}$ buffer in the $\mathrm{pH}$ range 8.0-10.0, and glycine/ $\mathrm{NaOH}$ buffer at $\mathrm{pH}$ 11.0. To determine the effect of $\mathrm{pH}$ on the stability of MTG, the enzyme was preincubated with the corresponding buffer $\left(1: 1\right.$ ratio) at $37^{\circ} \mathrm{C}$ for different durations, and the residual enzyme activity was measured.

The optimal temperature of MTG was measured at $10^{\circ} \mathrm{C}, 20^{\circ} \mathrm{C}, 30^{\circ} \mathrm{C}, 40^{\circ} \mathrm{C}, 50^{\circ} \mathrm{C}, 60^{\circ} \mathrm{C}$, and $70^{\circ} \mathrm{C}(\mathrm{pH} 7.0)$. To determine the effect of temperature on MTG stability, the enzyme solution was incubated at $20^{\circ} \mathrm{C}$ to $60^{\circ} \mathrm{C}$. Samples were selected every hour and the residual enzymatic activity was measured.

The effect of different chemical substances such as dimethyl sulfoxide (DMSO), phenylmethylsulphonyl fuoride (PMSF), ethylene diamine tetraacetic acid (EDTA), sodium dodecyl sulfate (SDS), Tween-20, $\beta$ Mercaptoethanol ( $\beta$-ME), a few metal ions, and other organic solvents on MTG was studied. All chemicals were preincubated at $37^{\circ} \mathrm{C}$ for $30 \mathrm{~min}$. Then the residual enzymatic activity was measured after mixing with purified TG at $37^{\circ} \mathrm{C}$ for $10 \mathrm{~min}$. The effect of $\mathrm{NaCl}$ concentrations on $\mathrm{MTG}$ was measured at $2 \%, 4 \%, 6 \%, 8 \%, 10 \%, 12 \%$, and $14 \%$ at $37^{\circ} \mathrm{C}$ for $10 \mathrm{~min}$.

The Michaelis-Menten equation was used to determine the kinetic parameters of MTG, which were examined under the substrate of CBZ-Gln-Gly from 5 to $30 \mathrm{mmol} / \mathrm{l}\left(\mathrm{pH}\right.$ 6.0). The values of Michaelis constant $\left(\mathrm{K}_{\mathrm{m}}\right)$ and maximum velocity $\left(\mathrm{V}_{\max }\right)$ of MTG were calculated from the Lineweaver-Burk plot.

\section{Effect of MTG on Gelatin Properties}

Measurement of gelling time and gel strength. Gelatin (240-270 Bloom) was purchased from Sangon Biotech (China). MTG was obtained from Bacillus subtilis SCK6 (pMA Ync M-TGSO). Gelatin in different concentrations $(6 \%, 8 \%, 10 \%, 12 \%$, and $14 \%)$ was weighed and dissolved in distilled water at $50^{\circ} \mathrm{C}$. To this, MTG $(0.1,0.2$, and $0.5 \mathrm{U} / \mathrm{ml}$ ) was added and mixed. The gelatin was reacted at $42^{\circ} \mathrm{C}$ and the length of time until the solution could be tilted $90^{\circ}$ with no liquid flowing out, was measured. Note: The meaning of this sentence is not clear.

The gel strength before and after MTG modification was measured using a texture analyzer (TA-XT Plus Texture Analyser, Lotun Science Co., Ltd., China). Gels were compressed at a rate of $1 \mathrm{~mm} / \mathrm{s}$ with P/10R probe until $4 \mathrm{~mm}$ of penetration was reached. The maximum force for gelatin was considered as gel strength.

Differential scanning calorimetry (DSC). Thermal properties of gelatin were measured by DSC (204 F1, NETZSCH, Germany). After the gel was freeze-dried, samples (3-5 mg) were sealed in an aluminum pan to measure the DSC value, and then heated from $10^{\circ} \mathrm{C}$ to $150^{\circ} \mathrm{C}$ at a rate of $10^{\circ} \mathrm{C} / \mathrm{min}$. Meanwhile, an empty aluminum crucible was used for comparison.

Fourier transform infrared spectroscopy (FTIR). FTIR spectra of gel were determined using FTIR spectrometer (Nicolet IS 10, Thermo Scientific, USA). The hydrogel, before and after modification, was freezedried to obtain a dry sponge. With 5-10 mg of dried gel, we used the potassium bromide grinding and tableting method to make a circular sheet. The round tablet was fixed to the sample holder of the infrared spectrometer. Infrared scanning was performed in the spectral range of $4,000 \sim 500 \mathrm{~cm}^{-1}$, and the infrared spectra of gels before and after modification were obtained.

\section{Results and Discussion}

\section{Cloning and Expression of MTG}

The Streptomyces MTG ORF consists of sequences that code for a secretory signal peptide, a pro-peptide gene, and a mature MTG gene. The upstream sequences of the ORF contain a putative promoter and the downstream sequences contain a putative terminator [28]. Bacillus subtilis is one of the most widely used hosts for protein production due to high secretion, excellent safety, clear genetic background, and well-developed fermentation technology [21]. In order to express the MTG in B. subtilis SCK6, the MTG gene (pro-mature, 1,149 bp) amplified from Streptomyces sp. TYQ1024 genome was inserted downstream of a secretion signal lipA in pMA lipA vectors which resulted in the plasmid pMA lipA-TG (Fig. 1A). The MTG activity of the culture supernatant arrived at 2.34 $\mathrm{U} / \mathrm{ml}$, after shake-flask fermentation for $60 \mathrm{~h}$ (Fig. 1C).

\section{Codon and Signal Peptide Optimization of MTG Gene}

To improve MTG expression in Bacillus subtilis SCK6, the codon of MTG was optimized for expression in Bacillus and was chemically synthesized by Sangon Biotech. The codon-optimized MTG ORF was then cloned into BamHI-NheI sites of pMA lipA, which yielded pMA lipA-TGSO. pMA lipA-TGSO expression in B. subtilis SCK6 yielded the highest MTG $(3.92 \mathrm{U} / \mathrm{ml})$ at $60 \mathrm{~h}$, which was $67.5 \%$ more than the control strain produced by pMA lipA-TG expression in B. subtilis SCK6 at $60 \mathrm{~h}(2.34 \mathrm{U} / \mathrm{ml})$ (Fig. 1C). This is consistent with the expression of MTG in Streptomyces lividans when certain rare codons were replaced with preferred codons and resulted in 73.6\% enhanced MTG production [23]. The low level of transfer RNA molecules prevents MTG expression when rare codon charged transfer RNA molecules are much lower than abundant codons [29]. The sequence optimization resulted in $67.5 \%$ more MTG production in B. subtilis SCK6. 

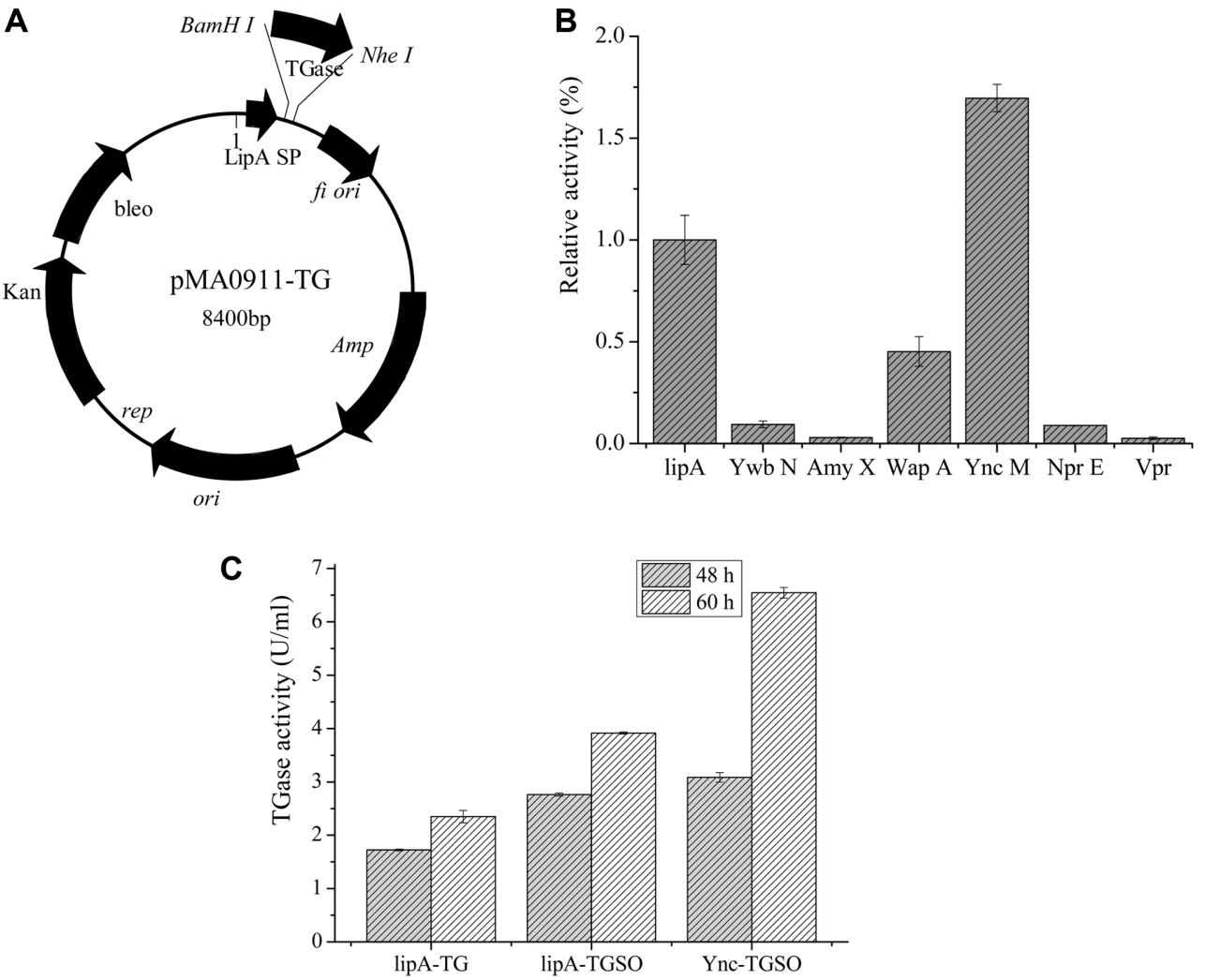

Fig. 1. Heterologous expression of transglutaminase in Bacillus subtilis SCK6 with codon and signal peptide optimization. (A) Expression of recombinant vector pMA lipA-TG. The signal peptide lipA is above BamHI ; the pro-TGase gene is inserted between the BamHI and NheI sites; (B) TGase activity assay of the different signal peptide. (C) The recombinant pMA lipA-TG; pMA lipA-TGSO; pMA YncM-TGSO were inoculated into $50 \mathrm{ml}$ of medium (containing $50 \mu \mathrm{g} /$ $\mathrm{ml} \mathrm{Kan)}$ and cultured at $37^{\circ} \mathrm{C}$ and $200 \mathrm{rpm}$ for $48 \mathrm{~h}$ and $60 \mathrm{~h}$, respectively.

To improve the extracellular expression of MTG, three signal peptides $\left(\mathrm{SP}_{\mathrm{YncM}}, \mathrm{SP}_{\mathrm{NprE}}\right.$, and $\left.\mathrm{SP}_{\mathrm{Vpr}}\right)$ from the Sec pathway and four signal peptides $\left(\mathrm{SP}_{\mathrm{YwbN}}, \mathrm{SP}_{\mathrm{LipA}}, \mathrm{SP}_{\mathrm{AmyX}}\right.$, and $\left.\mathrm{SP}_{\text {WapA }}\right)$ from the Tat pathway were selected to construct recombinant MTG plasmid. The recombinant strains with different signal peptides were incubated in the fermentation liquid medium to determine extracellular MTG activity for $60 \mathrm{~h}$. Among the seven signal peptides, $\mathrm{SP}_{\text {YncM }}$ exhibited a secretion efficiency of $6.7 \mathrm{U} / \mathrm{ml}$, which was $69 \%$ more than $\mathrm{SP}_{\mathrm{LipA}}$. Meanwhile, the other signal peptides $\left(\mathrm{SP}_{\mathrm{WapA}}\right.$ and $\mathrm{SP}_{\mathrm{YwbN}}$ ) showed a lower secretion efficiency (Fig. 1B). These findings confirm that Sec-pathway signal peptide $\mathrm{SP}_{\mathrm{YncMA}}$ directs efficient MTG secretion.

\section{Purification and Biochemical Characterization of MTG}

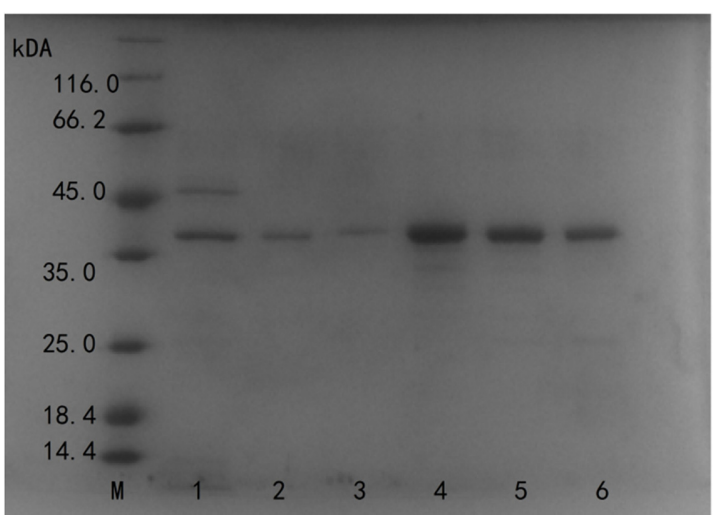

Fig. 2. SDS-PAGE analysis of purified TGase. M Protein Marker in different molecular weight size; lane 1 was fermentation supernatant; lanes 2, 3, 4, 5, 6 were purified active TGase by SP FF. 
Table 1. Purification of TGase.

\begin{tabular}{lccccc}
\hline \multicolumn{1}{c}{ Purification step } & Total activity $(\mathrm{U})$ & Total protein $(\mathrm{mg})$ & Specific activity $(\mathrm{U} / \mathrm{mg})$ & Purification fold & Yield $(\%)$ \\
\hline Supernatant & 3186.46 & 426.47 & 7.47 & 1 & 100 \\
Ammonium sulfate & 2556.77 & 100.24 & 25.51 & 3.41 & 80.20 \\
SP FF & 744.31 & 11.68 & 63.75 & 8.53 & 23.36 \\
\hline
\end{tabular}

Bacillus subtilis SCK6 expressed MTG as a soluble protein when incubated at $37^{\circ} \mathrm{C}$ for $60 \mathrm{~h}$. The fermentation supernate was initially precipitated with $50 \%-80 \%$ saturated ammonium sulfate. Then, the precipitate was dissolved in $20 \mathrm{mM} \mathrm{PB}$ at pH 5.8 (buffer A) and was subjected to SP Sepharose Fast Flow. The purified, mature MTG had a molecular mass of $38 \mathrm{kDa}$ (SDS-PAGE, lane 2 to 6; Fig. 2). The purified enzyme exhibited a specific activity of $63.75 \mathrm{U} / \mathrm{mg}$ of protein with 8.53 -fold purification and $23.36 \%$ recovery compared to the fermentation supernatant (Table 1). Compared with the commonly used E. coli expression system, Bacillus subtilis does not form inclusion bodies and endotoxin. Moreover, the extracellular expression of MTGase effectively avoids
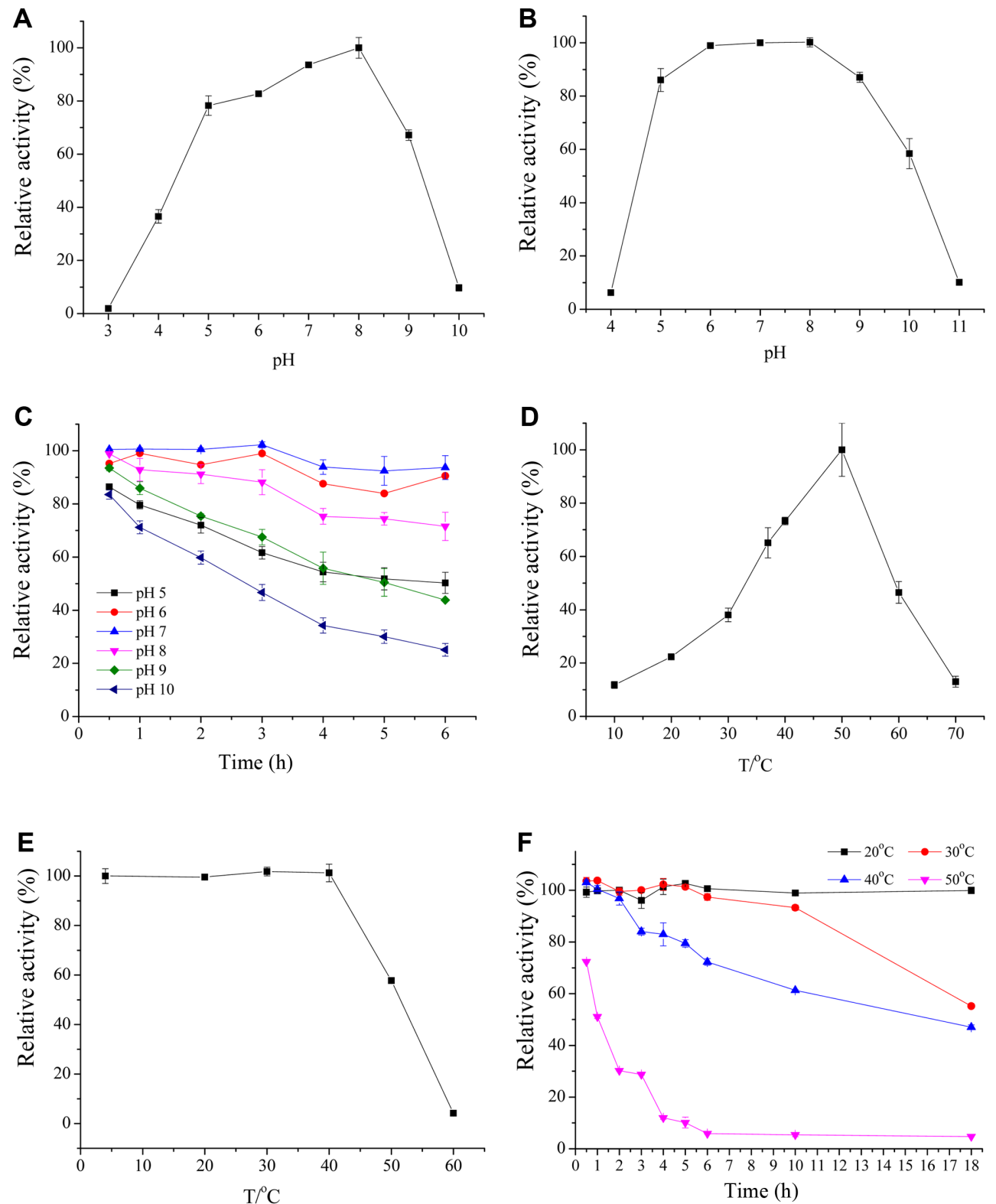

Fig. 3. Effects of $\mathrm{pH}$ and temperature on the activity and stability of MTGase. (A) Activity of MTGase at different $\mathrm{pH} ;(\mathbf{B})$ stability and $\mathrm{pH}$ at $30 \mathrm{~min}$; (C) stability and $\mathrm{pH}$ at $30 \mathrm{~min}$ to $6 \mathrm{~h}$; (D) activity of MTGase at different temperatures; (E) stability and temperature at $30 \mathrm{~min}$; (F) stability and temperature at $30 \mathrm{~min}$ to $18 \mathrm{~h}$. 
Table 2. Effects of metal ions on TGase activity.

\begin{tabular}{lcc}
\hline Metalions & Concentration & Residual activity $(\%)$ \\
\hline $\mathrm{Control}^{2+}$ & - & $100 \pm 2.33$ \\
$\mathrm{Ca}^{2+}$ & $5 \mathrm{mM}$ & $101.32 \pm 0.14$ \\
$\mathrm{Cu}^{2+}$ & $5 \mathrm{mM}$ & $35.76 \pm 0.071$ \\
$\mathrm{Mn}^{2+}$ & $5 \mathrm{mM}$ & $96.23 \pm 0.28$ \\
$\mathrm{Mg}^{2+}$ & $5 \mathrm{mM}$ & $101.04 \pm 2.05$ \\
$\mathrm{Fe}^{2+}$ & $5 \mathrm{mM}$ & $11.98 \pm 0.35$ \\
$\mathrm{Zn}^{2+}$ & $5 \mathrm{mM}$ & $32.83 \pm 0.42$ \\
$\mathrm{Fe}^{3+}$ & $5 \mathrm{mM}$ & $14.90 \pm 0.85$ \\
$\mathrm{Ni}^{+}$ & $5 \mathrm{mM}$ & $64.91 \pm 0.84$ \\
$\mathrm{Li}^{+}$ & $5 \mathrm{mM}$ & $94.13 \pm 2.33$ \\
$\mathrm{Ba}^{2+}$ & $5 \mathrm{mM}$ & $101.56 \pm 1.13$ \\
$\mathrm{Co}^{2+}$ & $5 \mathrm{mM}$ & $91.01 \pm 1.77$ \\
$\mathrm{Cr}^{3+}$ & $5 \mathrm{mM}$ & $5.53 \pm 0.92$ \\
$\mathrm{CrO}_{4}^{2-}$ & $5 \mathrm{mM}$ & $25.98 \pm 1.63$ \\
$\mathrm{~Pb}^{2+}$ & $5 \mathrm{mM}$ & $69.44 \pm 2.48$ \\
$\mathrm{~K}^{+}$ & $5 \mathrm{mM}$ & $102.00 \pm 2.22$ \\
\hline
\end{tabular}

complicated operations, such as cell disruption, dilution and renaturation, which facilitates the separation and purification of enzymes. Yokoyama K expressed MTGase in E. coli JM 109 reached enzyme activity of $1.35 \mathrm{U} / \mathrm{ml}$ with refolding and renaturation in vitro [30]. Yi-Sin Lin expressed mtgA from Streptomyces platensis in Streptomyces lividans JT46/pAE053 with $2.2 \mathrm{U} / \mathrm{ml}$ MTGase activity [31]. In this study, the MTGase expressed in B.subtilis SCK6 exhibited a secretion efficiency of $6.7 \mathrm{U} / \mathrm{ml}$, showed a large yield advantage and effectively reduced the cost of industrial production.

The $\mathrm{pH}$ of the reaction mixture affects the conformation and configuration of the active and catalytic sites of the enzyme as well as the net charge of the protein in its hydrogen bonding pattern [32]. Therefore, we investigated the effect of pH on MTG activity (pH 3.0-10.0; Fig. 3A). The optimum $\mathrm{pH}$ of MTG from recombinant SCK6 was in the range of 7 to 8, which is consistent with that observed for MTG from Streptomyces [33]. MTG was stable (residual activity $>70 \%$ ) over a wide range of $\mathrm{pH}(5.0-9.0)$ and maintained high stability (residual activity $>80 \%$ ) in the $\mathrm{pH}$ range of 6-7 after $6 \mathrm{~h}$ (Figs. $3 \mathrm{~B}$ and $3 \mathrm{C}$ ).

We further investigated the effect of temperature $\left(10-70^{\circ} \mathrm{C}\right)$ on the enzyme activity. MTG activity was maximum at $50^{\circ} \mathrm{C}$ (Fig. 3D). The optimal temperature of recombinant MTG in this study was similar to that of MTG isolated from Streptoverticillium mobarense, whereas, it was higher than that of MTG isolated from Streptomyces hygroscopicus $\left(37-45^{\circ} \mathrm{C}\right)$ [8]. MTG exhibited stable activity in the temperature range of 0 to $40^{\circ} \mathrm{C}$ at $30 \mathrm{~min}$, and the activity dropped at temperatures above $50^{\circ} \mathrm{C}$ (Fig. $3 \mathrm{E}$ ). There was no significant loss in enzyme activity at $20^{\circ} \mathrm{C}$; however, half of the MTG activity was lost at $30^{\circ} \mathrm{C}$ and $40^{\circ} \mathrm{C}$ at $18 \mathrm{~h}$ (Fig. 3F).

The relative activity of MTG was measured in the presence of different metal ions at $5 \mathrm{mM}$ concentration (Table 2). $\mathrm{Cr}^{3+}, \mathrm{Fe}^{2+}, \mathrm{Fe}^{3+}, \mathrm{Cu}^{2+}, \mathrm{Zn}^{2+}$, and $\mathrm{CrO}_{4}^{2-}$ strongly inhibited the enzyme activity, while $\mathrm{Ni}^{+}$and $\mathrm{Pb}^{2+}$ slightly

Table 3. Effects of chemicals and various surfactants on TGase activity.

\begin{tabular}{lcccc}
\hline Chemicals & Concentration & Residual activity $(\%)$ & Concentration & Residual activity (\%) \\
\hline Control & - & $100 \pm 1.5$ & - & $100 \pm 2.4$ \\
Tween 20 & $10 \%$ & $75.64 \pm 5.06$ & $5 \%$ & $93.26 \pm 4.34$ \\
Tween 80 & $10 \%$ & $67.58 \pm 23.83$ & $5 \%$ & $97.39 \pm 2.88$ \\
Glycerin & $10 \%$ & $99.02 \pm 6.42$ & $5 \%$ & $103.91 \pm 0.96$ \\
Acetone & $10 \%$ & $5.89 \pm 0.15$ & $5 \%$ & $89.72 \pm 1.89$ \\
Ethanol & $10 \%$ & $90.96 \pm 2.88$ & $5 \%$ & $101.96 \pm 0.95$ \\
Benzene & $10 \%$ & $96.46 \pm 0.46$ & $5 \%$ & $101.14 \pm 1.13$ \\
DMSO & $10 \%$ & $90.37 \pm 1.56$ & $5 \%$ & $99.41 \pm 0.47$ \\
Isopropanol & $10 \%$ & $91.75 \pm 2.92$ & $5 \%$ & $97.64 \pm 0.23$ \\
Formamide & $10 \%$ & $92.53 \pm 7.67$ & $5 \%$ & $97.98 \pm 2.49$ \\
Hexane & $10 \%$ & $96.46 \pm 0.31$ & $5 \%$ & $99.65 \pm 0.31$ \\
Urea & $0.5 \mathrm{M}$ & $86.15 \pm 1.56$ & $0.25 \mathrm{M}$ & $90.93 \pm 1.84$ \\
GNHCL & $0.5 \mathrm{M}$ & $89.88 \pm 1.91$ & $0.05 \%$ & $98.92 \pm 0.57$ \\
SDS & $0.1 \%$ & $7.641 \pm 5.66$ & $5 \mathrm{mM}$ & $2.9 \pm 3.25$ \\
$\beta$-ME & $10 \mathrm{mM}$ & $126.55 \pm 2.2$ & $5 \mathrm{mM}$ & $142.42 \pm 1.84$ \\
PMSF & $10 \mathrm{mM}$ & $4.85 \pm 5.60$ & $5 \mathrm{mM}$ & $7.46 \pm 0.50$ \\
DDT & $10 \mathrm{mM}$ & $150.57 \pm 1.85$ & $2.5 \%$ & $160.18 \pm 1.5$ \\
Tritonx-100 & $5 \%$ & $70.95 \pm 3.75$ & $0.5 \%$ & $92.99 \pm 2.7$ \\
$\mathrm{H}_{2} \mathrm{O}_{2}$ & $1 \%$ & $11.43 \pm 1$ & $10 \mathrm{mM}$ & $35.86 \pm 0.45$ \\
EGTA & $10 \mathrm{mM}$ & $99.43 \pm 2.5$ & $10 \mathrm{mM}$ & $101.17 \pm 1.1$ \\
EDTA & $10 \mathrm{mM}$ & $91.24 \pm 1.5$ & & $96.56 \pm 2.25$ \\
\hline
\end{tabular}




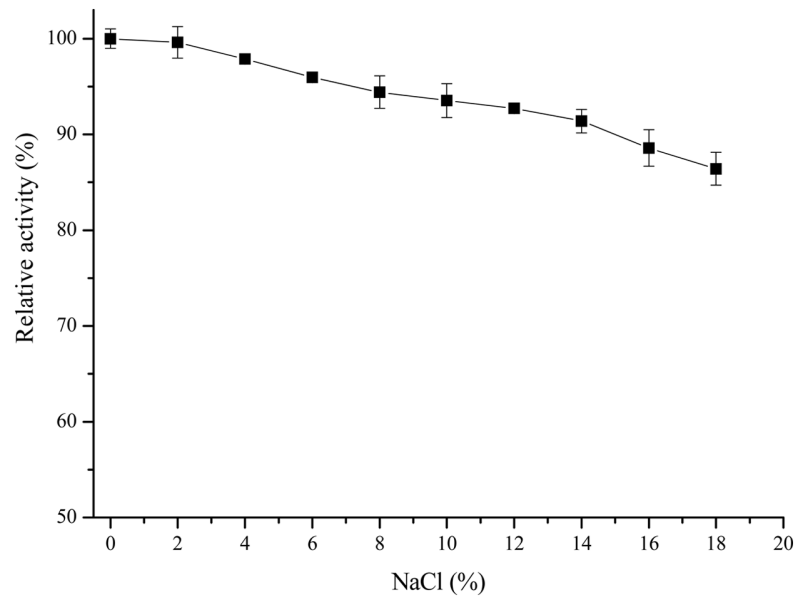

Fig. 4. TGase activities in different concentrations of $\mathrm{NaCl}$.

inhibited the activity. $\mathrm{Ca}^{2+}, \mathrm{Mn}^{2+}, \mathrm{Mg}^{2+}, \mathrm{Li}^{+}, \mathrm{Ba}^{2+}, \mathrm{Co}^{2+}$, and $\mathrm{K}^{+}$did not inhibit MTGase activity. The reductants DLDithiothreitol (DTT, $142.42 \pm 1.84 \%, 5 \%)$ and $\beta$-Mercaptoethanol $(\beta$-ME, $160.18 \pm 1.5,5 \mathrm{~mm}$ ) enhanced MTG activity, while PMSF and SDS inhibited MTG activity. $\mathrm{H}_{2} \mathrm{O}_{2}$ at $1 \%$ concentration completely inhibited MTG activity $(1.43 \pm 1 \%)$. In addition, when the concentration was reduced to $0.5 \%$, the inhibitory effect on $\mathrm{H}_{2} \mathrm{O}_{2}$ weakened $(35.86 \pm 0.45 \%)$. Interestingly, $10 \%$ acetone completely inhibited MTG activity, and the inhibition weakened as the concentration reduced to $5 \%$. Heavy metals such as $\mathrm{Cu}^{2+}, \mathrm{Fe}^{3+}, \mathrm{Zn}^{2+}$, and $\mathrm{Cr}^{3+}$ will bind the thiol group of the single cysteine residues to inhibit MTGase activity, which supports the theory that cysteine residues are the active site of MTGase [2]. Among them, $\mathrm{Ca}^{2+}$ has no obvious effect on enzyme activity, showing that the microbial source TGase is $\mathrm{Ca}^{2+}$ independent. There was no metal ion involved in the active center of the MTGase. Therefore, the metal ions such as $\mathrm{Ca}^{2+}, \mathrm{Mg}^{2+}, \mathrm{Li}^{+}, \mathrm{Ba}^{2+}$, and $\mathrm{K}^{+}$have little effect on the activity of MTGase. The antioxidants $\beta$-ME and DTT effectively promote the MTG enzyme activity. This may be that $\beta$-ME and DTT can protect the thiol group of the TGase active center from being oxidized, and meanwhile it can also reduce the crosslinked bond to a disulfide bond [34].

MTG activity in the presence of $\mathrm{NaCl}$ at different concentrations revealed $\mathrm{NaCl}$ tolerance of MTG (Fig. 4). MTG exhibited about $80 \%$ activity in the presence of $\mathrm{NaCl}$ at $18 \%$ concentration $(\mathrm{w} / \mathrm{v})$. This finding indicates it advantage over normal MTGs, which are unstable in salt. Salt is commonly used in food processing, and people in the Far East often use salt to marinate foods, especially protein foods such as pork, fish and sausages. These foods with salt have a longer storage time and a special flavor. In addition, Carlos Cardoso found that MTGase and salt have a synergistic effect on the production of high-quality gels from farmed sea bass, especially the enhancement of gel strength [35]. Therefore, this salt tolerance indicates the great potential of MTGase in high-salt food applications.

The kinetic parameters, $\mathrm{K}_{\mathrm{m}}$ and $\mathrm{V}_{\max }$, were determined as shown in the plot (Fig. 5). The Michaelis-Menten constant $\left(\mathrm{K}_{\mathrm{m}}\right)$ was $16.93 \mu \mathrm{M} / \mathrm{ml}$, whereas $\mathrm{V}_{\max }$ was $5.27 \mathrm{U} / \mathrm{min}$. A low value of $\mathrm{K}_{\mathrm{m}}$ indicates that the substrate is

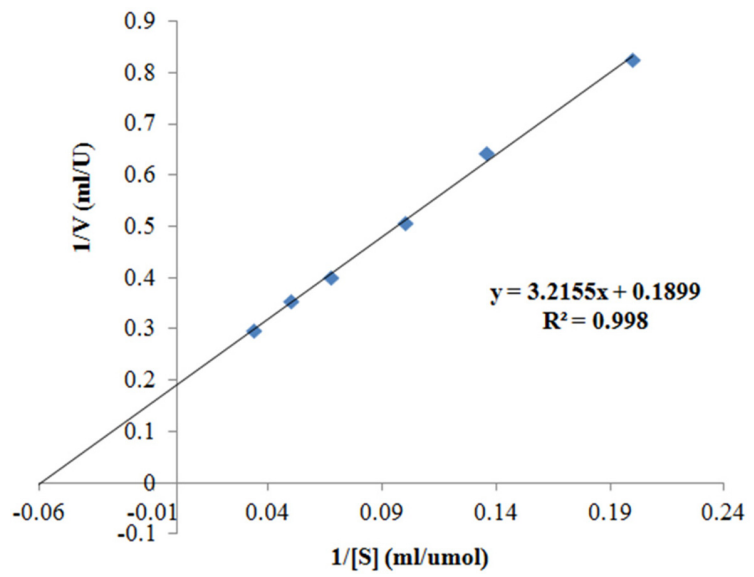

Fig. 5. Kinetic parameters of MTGase from SCK6. 

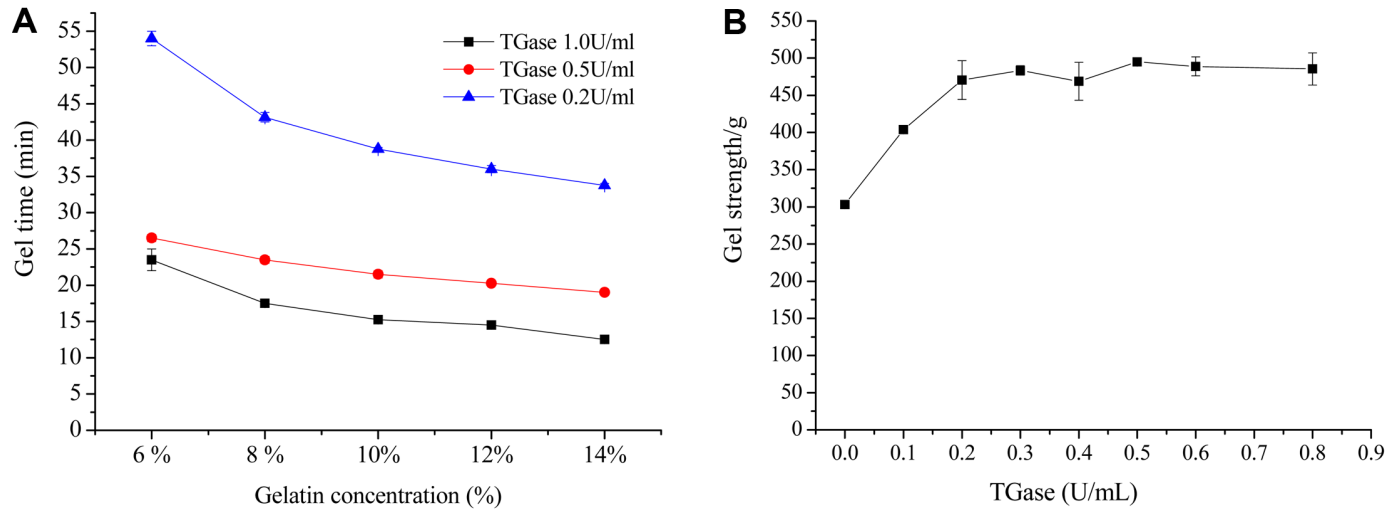

Fig. 6. (A) Influence of gelatin and TGase concentration on gelling time; (B) Effects of different concentrations of MTG on gel strength of gelatin gels.

held tightly and the enzyme will achieve maximum velocity at low substrate concentration.

\section{Effect of MTG on Gelatin Properties}

Gelling time and gel strength. The relationship between gelatin and MTG concentrations and the time required to form a gel is shown in Fig. 6A. With increase in gelatin concentration from $6 \%$ to $14 \%$, the gelling time had a significant reduction from $54 \mathrm{~min}$ to $33 \mathrm{~min}$ with addition of $0.2 \mathrm{U} / \mathrm{ml} \mathrm{MTG}$. Similarly, with increase in MTG concentration, gelling time decreased significantly. MTG at $1 \mathrm{U} / \mathrm{ml}$ completely cross-linked $14 \%$ gelatin in $11 \mathrm{~min}$. The gelatin at high concentration provided more cross-linking sites for MTG, which made the reaction proceed smoothly. In general, gelatin solution can be physically cross-linked between gelatin molecules to form a gel without adding any cross-linking agent when the temperature is below $29^{\circ} \mathrm{C}$ and dissolved into aqueous solution when temperatures are above $30^{\circ} \mathrm{C}$ [36]. Interestingly, MTG-cross-linked hydrogel did not hydrolyze at high temperatures, which expands the application of hydrogels.

Gel strength is one of the major physical properties of gelatin and is considered as a stiffness factor to predict physical properties [37]. The gel strength of MTG-modified gelatin first increased and then stabilized at $490 \mathrm{~g}$ with $0.3 \mathrm{U} / \mathrm{ml}$ of MTG, which was about 1.65-fold that of the control gel (Fig. 6B). The network structure of gel showed an obvious effect on its texture properties and closely entangled gels showed greater gel strength. MTG catalyzes the formation of covalent bonds, then propitiates a stronger and more stable gel network [38]. This indicated that the physical properties of the gel improved by MTG modification.

Differential scanning calorimetry (DSC). The thermal properties of gelatin were measured by differential scanning calorimetry (DSC), which is an effective method to provide the thermodynamic data (Tm). MTG provided to gelatin gels increased their thermal denaturation temperature (Fig. 7). The thermal denaturation temperature of modified gelatin gels increased from 61.8 to $75.8^{\circ} \mathrm{C}$ with increase in MTG concentration from 0 to $0.3 \mathrm{U} / \mathrm{ml}$. This is consistent with the findings of Liu Fei et al. who found that MTG improved the mechanical and thermal properties of cross-linked gelatin film [39]. However, as the MTG enzyme concentration increased to

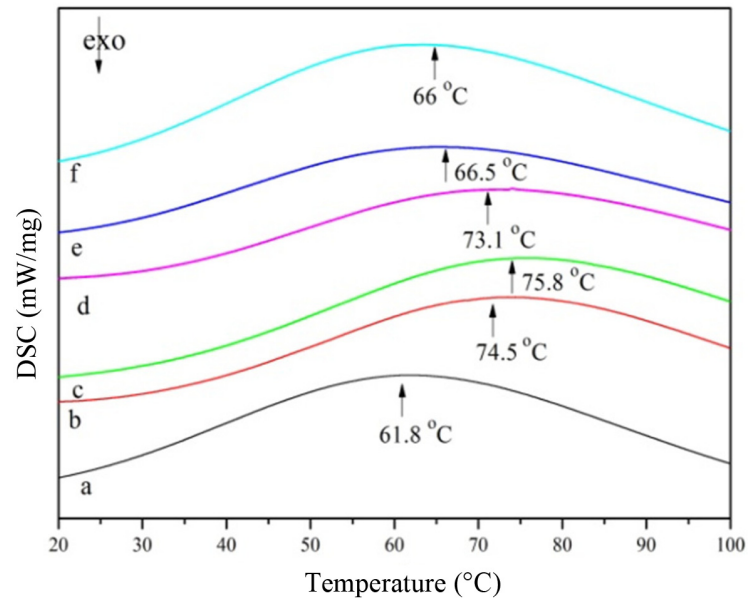

Fig. 7. Effects of different concentrations of MTG on thermal stability of gelatin. a: $0 \mathrm{U} / \mathrm{ml} ; \mathrm{b}: 0.1 \mathrm{U} / \mathrm{ml} ; \mathrm{c:}: 0.2 \mathrm{U} / \mathrm{ml}$; d: $0.3 \mathrm{U} / \mathrm{ml}$; e: $0.4 \mathrm{U} / \mathrm{ml}$; f: $0.5 \mathrm{U} / \mathrm{ml}$. 


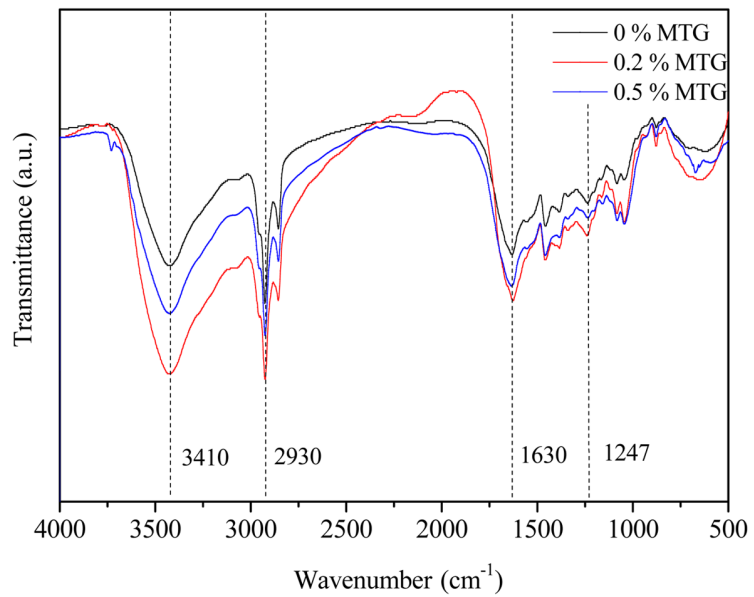

Fig. 8. FI-IR spectrum of crosslinked gelatin gels under different concentrations of MTG.

$0.5 \mathrm{U} / \mathrm{ml}$, the thermal denaturation temperature of the modified gelatin decreased from 75.8 to $66^{\circ} \mathrm{C}$. This may be due to the cross-linking of gelatin under the catalysis of MTG, which formed gel networks with higher molecular weight and made the gelatin tangles tighter and the voids smaller [40]. Therefore, the bonds of network structure between gelatin in the presence of MTG are more difficult to break. At MTG concentrations above $0.3 \mathrm{U} / \mathrm{ml}$, the local reaction inside the gelatin may cause a steric hindrance effect, which is not conducive to improving the thermal stability.

Fourier transformation infrared (FTIR) spectroscopy. FTIR spectra of cross-linked gels at different concentrations of MTG are shown in Fig. 8. The gelatin spectral distribution showed characteristic absorption bands. The absorption band near $3,410 \mathrm{~cm}^{-1}$ corresponds to amide $\mathrm{A}$ and may be assigned to the vibration of $\mathrm{OH}$ and $\mathrm{NH}$ groups [41]. The absorption band near $2,930 \mathrm{~cm}^{-1}$ corresponds to the amide $\mathrm{B}$ and may be assigned to the vibration of $=\mathrm{C}-\mathrm{H}$ and $-\mathrm{NH}$ groups [42]. The characteristic absorption bands of amide $\mathrm{I}(\mathrm{C}=\mathrm{O}$ and $\mathrm{CN}$ stretching vibration), amide II ( $\mathrm{NH}$ and $\mathrm{CN}$ groups vibrations), and amide III (vibrations of $\mathrm{NH}$ and $\mathrm{CN}$ groups) were observed at $1,630,1,547$, and $1,240 \mathrm{~cm}^{-1}$, respectively [43]. The absorption peaks did not shift significantly when gelatin was modified with MTG at different concentrations. FTIR spectra showed that the band strength of amide A and amide I enhanced, which was due to the addition of MTG that promoted the cross-linking of gelatin (to form more isopeptide bonds) and increased the number of NH bonds.

In this study, codon and signal peptide optimization improved the extracellular expression of MTG in B. subtilis SCK6 (Ync M-TGSO) which showed the highest extracellular MTG activity (6.7 U/ml, 2.86-fold). The enzyme showed maximum activity at $\mathrm{pH} 8$ and $50^{\circ} \mathrm{C}$. The recombinant MTG showed tolerance to sodium chloride and organic solvents. The strength and thermal stability of gelatin significantly increased with MTG cross-linking. This is the first study to report the secretion of MTG in Bacillus subtilis SCK6, with a final recovery of $63.75 \mathrm{U} / \mathrm{mg}$ without any chemical inducer. In conclusion, this study provides a new strategy for the efficient production of MTG that could be used in salt-containing foods.

\section{Acknowledgment}

This work was financially supported by the National Key Research and Development Program of China (20 18YFC1802201) and the Opening Project of Key Laboratory of Leather Chemistry and Engineering, (Sichuan University), Ministry of Education(20826041C4159).

\section{Conflict of Interest}

The authors have no financial conflicts of interest to declare.

\section{References}

1. Lorand L, Graham RM. 2003. Transglutaminases: crosslinking enzymes with pleiotropic functions. Nat. Rev. Mol. Cell Biol. 4: 140156.

2. Yokoyama K, Nio N, Kikuchi Y. 2004. Properties and applications of microbial transglutaminase. Appl. Microbiol. Biotechnol. 64: 447-454.

3. Liu S, Wan D, Wang M. 2015. Overproduction of pro-transglutaminase from Streptomyces hygroscopicus in Yarrowia lipolytica and its biochemical characterization. BMC Biotechnol. 15: 75 .

4. Duran R, Junqua M, Schmitter JM. 1998. Purification, characterisation, and gene cloning of transglutaminase from Streptoverticillium cinnamoneum CBS 683.68. Biochimie 80: 313-319.

5. Ando H, Adachi M, Umeda K, Matsuura A, Nonaka M, Uchio R. 1989. Purification and characteristics of a novel transglutaminase derived from microorganisms. Agric. Biol. Chem. 53: 2613-2617.

6. Casadio R, Polverini E, Mariani P, Spinozzi F. 1999. The structural basis for the regulation of tissue transglutaminase by calcium ions. Eur. J. Biochem. 262: 672-679. 
7. Kobayashi K, Suzuki SI, Izawa Y, Miwa K, Yamanaka S. 1998. Transglutaminase in sporulating cells of Bacillus subtilis. J. Gen. Appl. Microbiol. 44: 85-91.

8. Sorde KL, Ananthanarayan L. 2019. Isolation, screening, and optimization of bacterial strains for novel transglutaminase production. Prep. Biochem. Biotechol. 49: 64-73.

9. Zhu Y, Tramper J. 2008. Novel applications for microbial transglutaminase beyond food processing. Trends Biotechnol. 26: $559-565$.

10. Zotzel J, Keller P, Fuchsbauer HL. 2003. Transglutaminase from Streptomyces mobaraensis is activated by an endogenous metalloprotease. Eur. J. Biochem. 270: 3214-3222

11. Washizu K, Ando K, Koikeda S. 1994. Molecular cloning of the gene for microbial transglutaminase from Streptoverticillium and its expression in Streptomyces lividans. Biosci. Biotechnol. Biochem. 58: 82-87.

12. Kikuchi Y, Date M, Yokoyama KI. 2003. Secretion of active-form Streptoverticillium mobaraense transglutaminase by Corynebacterium glutamicum: Processing of the pro-transglutaminase by a cosecreted subtilisin-like protease from Streptomyces albogriseolus. Appl. Environ. Microbiol. 69: 358-366.

13. Yang HL, Pan L, Lin Y. 2009. Purification and on-column activation of a recombinant histidine-tagged pro-transglutaminase after soluble expression in Escherichia coli. Biosci. Biotechnol. Biochem. 73: 2531-2534.

14. Liu S, Zhang DX, Wang M. 2011. The order of expression is a key factor in the production of active transglutaminase in Escherichia coli by co-expression with its pro-peptide. Microb. Cell Fact. 10: 112-120.

15. Noda S, Miyazaki T, Tanaka T. 2013. High-level production of mature active-form Streptomyces mobaraensis transglutaminase via pro-transglutaminase processing using Streptomyces lividans as a host. Biochem. Eng. J. 74: 76-80.

16. Yurimoto H, Yamane M, Kikuchi Y. 2014. The pro-peptide of streptomyces mobaraensis transglutaminase functions in cis and in trans to mediate efficient secretion of active enzyme from methylotrophic yeasts. Biosci. Biotech. Biochem. 68: 2058-2069.

17. Date M, Yokoyama KI, Umezawa Y. 2004. High level expression of Streptomyces mobaraensis transglutaminase in Corynebacterium glutamicum using a chimeric pro-region from Streptomyces cinnamoneus transglutaminase. J. Biotechnol. 110: 219-226.

18. Shaista B, Saima S, Sajjad A. 2015. Enhanced and secretory expression of human granulocyte colony stimulating factor by Bacillus subtilis SCK6. BioMed. Res. Int. 2015: 1-9.

19. Simonen M, Palva I. 1993. Protein secretion in Bacillus species. Microbiol. Rev. 57: 109-137.

20. Fu LL, Xu ZR, Li WF. 2007. Protein secretion pathways in Bacillus subtilis: implication for optimization of heterologous protein secretion. Biotechnol Adv. 25: 1-12.

21. Tian JW, Long XF, Tian YQ. 2019. Enhanced extracellular recombinant keratinase activity in Bacillus subtilis SCK6 through signal peptide optimization and site-directed mutagenesis. RSC Adv. 9: 33337-33344.

22. Fu G, Liu J, Li J. 2018. Systematic screening of optimal signal peptides for secretory production of heterologous proteins in Bacillus subtilis. J. Agr. Food Chem. 66: 13141-13151.

23. Liu S, Wang M, Du G. 2016. Improving the active expression of transglutaminase in Streptomyces lividans by promoter engineering and codon optimization. BMC Biotechnol. 16: 75 .

24. Tian JW, Xu Z, Long XF, Tian YQ. 2019. High-expression keratinase by Bacillus subtilis SCK6 for enzymatic dehairing of goatskins. Int. J. Biol. Macromol. 135: 119-126.

25. Li WJ, Xu P, Schumann P. 2007. Georgenia ruanii sp. nov., a novel actinobacterium isolatedfrom forest soil inYunnan(China), and emended description of the genus Georgenia, Int. J. Syst. Evol. Micr. 57: 1424-1428.

26. Zhang XZ, Zhang YHP. 2011. Simple, fast and high-efficiency transformation system for directed evolution of cellulase in Bacillus subtilis. Microb. Biotechnol. 4: 98-105.

27. Folk JE, Cole PW. 1966. Mechanism of action of guinea pig liver transglutaminase. J. Biol. Chem. 241: 5518-5525.

28. Liu S, Zhang DX. 2011. The pro-region of Streptomyces hygroscopicus transglutaminase affects its secretion by Escherichia coli. FEMS Microbiol. Lett. 324: 98-105.

29. Binnie C, Cossar JD, Stewart DIH. 1997. Heterologous biopharmaceutical protein expression in Streptomyces. Trends Biotechnol. 15: 315-320.

30. Yokoyama KI, Nakamura N, Seguro K. 2000. Overproduction of microbial transglutaminase in Escherichia coli, in vitro refolding, and characterization of the refolded form. Biosci. Biotechnol. Biochem. 64: 1263-1270.

31. Lin YS, Chao ML, Liu CH. 2006. Cloning of the gene coding for transglutaminase from Streptomyces platensis and its expression in Streptomyces lividans. Process Biochem. 41: 519-524.

32. Chaudhari. 2017. Non-covalent conjugation of cutinase from Fusarium sp. ICT SAC1 with pectin for enhanced stability: Process minutiae, kinetics, thermodynamics and structural study. Int. J. Biol. Macromol. 102: 729-740.

33. Cui L, Du G, Zhang D. 2007. Purification and characterization of transglutaminase from a newly isolated Streptomyces hygroscopicus. Food Chem. 105: 612-618.

34. Anulak, Worratato, Jirawat. 2003. Cross-linking of actomyosin by crude tilapia (oreochromis niloticus) transglutaminase. J. Food Biochem. 27: 35-51.

35. Cardoso C, Rogério Mendes, Vaz-Pires P. 2010. Effect of salt and MTGase on the production of high quality gels from farmed sea bass. J. Food Eng. 101: 98-105.

36. Kirchmajer DM, Watson CA, Ranson M. 2012. Gelapin, a degradable genipin cross-linked gelatin hydrogel. RSC Adv. 3: $1073-1081$.

37. Huang T, Tu ZC, Shangguan X. 2017. Rheological behavior, emulsifying properties and structural characterization of phosphorylated fish gelatin. Food Chem. 246: 428-436.

38. Huang T, Zhao HZ. 2019. Comparison of gelling properties and flow behaviours of microbial transglutaminase (MTGase) and pectin modified fish gelatin. J. Texture Stud. 50: 400-409.

39. Liu F, Chiou BS, Avena-Bustillos RJ. 2016. Study of combined effects of glycerol and transglutaminase on properties of gelatin films. Food Hydrocolloid. 65: 1-9.

40. Wangtueai S, Noomhorm A, Regenstein JM. 2010. Effect of microbial transglutaminase on gel properties and film characteristics of gelatin from lizardfish (saurida spp.) scales. J. Food Sci. 75: C731-C739.

41. Jridi M, Hajji S, Ayed HB. 2014. Physical, structural, antioxidant and antimicrobial properties of gelatin-chitosan composite edible films. Int. J Biol. Macromol. 67: 373-379.

42. Hamzeh A, Benjakul S, Sae-Leaw T. 2018. Effect of drying methods on gelatin from splendid squid (Loligo formosana) skins. Food Biosci. 26: 96-103.

43. Luã Caldas de Oliveira. 2019. Improvement of the characteristics of fish gelatin-gum arabic through the formation of the polyelectrolyte complex. Carbohydr. Polym. 223: 115068. 